\title{
PENINGKATAN STATUS HAK GUNA BANGUNAN MENJADI HAK MILIK
}

\author{
Atik Winanti ${ }^{1}$, Taupiqqurrahman ${ }^{2}$, dan Rosalia Dika Agustanti ${ }^{3}$ \\ ${ }^{1,2,3}$ Fakultas Hukum Universitas Pembangunan Nasional Veteran Jakarta
}

\begin{abstract}
Article 33 paragraph (3) of the 1945 Constitution which reads Earth, water and natural resources in it are controlled by the State and used for the greatest prosperity of the people. This article is one of the foundations for the birth of a law on basic agrarian principles. In the UUPA, land rights include property rights, rights to build, right to cultivate, use rights and other rights.So far, people in Indonesia control land with the status of ownership rights and building use rights. The strongest and most fulfilled status of land a person has is only property rights. Meanwhile, the right to build only has a certain period. We chose a place of service in the village of Satria Jaya because in this village there is a housing complex, namely Perum Graha Prima which is intended for Civil Servants and Members of the Indonesian National Army who are certified Building Use Rights. Most of the residents in this housing do not know how to qualify and how to change their rights position. From building use rights to ownership rights. So that giving understanding to the community about the importance of property rights and how to improve the position of land rights is a solution given to local communities. The implementation of community service activities is carried out virtually by using the Zoom application. Where the resource person delivered material about Property Rights, Building Use Rights and the process of increasing the status of land rights.
\end{abstract}

Keywords: Status Enhancement, Building rights, Right of ownership.

\begin{abstract}
ABSTRAK
Pasal 33 ayat (3) Undang-undang Dasar 1945 yang berbunyi Bumi, air dan kekayaan alam di dalamnya dikuasai oleh Negara dan dipergunakan untuk sebesar-besarnya kemakmuran rakyat. Pasal tersebut sebagai salah satu landasan lahirnya undang-undang tentang peraturan dasar pokok-pokok agraria (UUPA). Dalam UUPA hak-hak atas tanah meliputi hak milik, hak guna bangunan, hak guna usaha, hak pakai dan hak lainnya. Sejauh ini, masyarakat di Indonesia menguasai tanah dengan status hak milik dan hak guna bangunan. Status tanah yang terkuat dan terpenuh yang dimiliki seseorang hanyalah hak milik. Sedangkan hak guna bangunan hanya mempunyai jangka waktu tertentu. Kami memilih tempat pengabdian di desa Satria Jaya karena di Desa ini terdapat Perumahan yaitu Perum Graha Prima yang diperuntukkan bagi PNS dan Anggota TNI yang bersertifikat Hak Guna Bangunan (HGB). Hampir sebagian besar penduduk di perumahan tersebut tidak mengetahui bagaimana persyaratan dan caranya untuk merubah status hak dari Hak Guna Bangunan menjadi Hak Milik. Sehingga pemberian pemahaman kepada masyarakat tentang pentingnya hak milik serta bagaimana peningkatan status hak katas tanah menjadi solusi yang diberikan kepada masyarakat setempat. Kegiatan pelaksanaan pengabdian dilakukan secara virtual dengan mempergunakan aplikasi Zoom. Di mana narasumber menyampaikan materi tentang Hak Milik, Hak Guna Bangunan dan proses peningkatan status hak atas tanah.
\end{abstract}

Kata Kunci: Peningkatan Status, Hak Guna Bangunan, Hak Milik.

\section{PENDAHULUAN}

Pada negara agraris seperti Indonesia, tanah merupakan faktor produksi sangat penting karena menentukan kesejahteraan hidup penduduk negara yang bersangkutan. Paling sedikit ada tiga kebutuhan dasar manusia yang menggunakan tanah. Pertama, tanah sebagai sumber ekonomi sebagai penunjang kehidupan. Kedua, tanah sebagai tempat mendirikan rumah atau bagunan untuk tempat tinggal. Ketiga, tanah yang difungsikan sebagai pemakaman. (G.Kartasapoetra dkk. 1991:12 ) Walaupun tanah di negara agraris merupakan kebutuhan dasar, tetapi struktur kepemilikan tanah di negara agraris biasanya sangat timpang. Di satu sisi ada individu atau kelompok manusia yang memiliki dan menguasai tanah secara berlebihan, di satu sisi lainnya terdapat kelompok manusia yang sama sekali tidak memiliki tanah. Kepincangan atas pemilikan tanah inilah yang membuat seringnya permasalahan tanah di negara-negara agraris menjadi salah satu sumber utama dari kepentingan politik. 
Dengan demikian maka jelaslah bahwa tanah sebagai sumber utama bagi kehidupan manusia, yang telah dikaruniakan oleh Tuhan Yang Maha Esa sebagai tumpuan masa depan kesejahteraan manusia itu sendiri, manusia wajib dalam pendayagunaan dan pengelolaannya memperhatikan hukum alam dan hukum masyarakat, agar antara hak-hak dan kewajiban-kewajiban atas tanah selalu berimbang sehingga kemampuan tanah sebagai sumber utama kehidupan manusia dapat berlangsung terus sepanjang masa.

Berdasarkan pasal 33 ayat (3) Undang-Undang Dasar 1945 yang berbunyi Bumi, air dan kekayaan alam di dalamnya dikuasai oleh Negara dan dipergunakan untuk sebesar-besarnya kemakmuran rakyat. Dari pasal ini dapat diartikan bahwa segala sesuatu yang berada di atas tanah maupun terkandung di dalamnya dikuasai oleh negara. Wewenang yang diberikan kepada negara ini tidaklah semata-mata tanpa kewajiban. Negara memiliki wewenang bertujuan agar penggunaan dan pembagian hasil kekayaan alam yang dimiliki dapat dirasakan oleh seluruh rakyat Indonesia. Dengan adanya pasal di atas juga dapat membatasi hak para pihak yang berkaitan dengan tanah. Selain yang diatur dalam Undang-Undang Dasar 1945, ketentuan akan kekayaan alam Indonesia juga diatur dalam Undang-undang Nomor 5 Tahun 1960 tentang Peraturan Dasar Pokok-Pokok Agraria: "Atas dasar ketentuan dalam Pasal 33 ayat 3 Undang-Undang Dasar dan hal-hal sebagai yang dimaksud dalam Pasal 1, bumi, air, dan ruang angkasa, termasuk kekayaan alam yang terkandung didalamnya itu pada tingkatan tertinggi dikuasai oleh negara, sebagai organisasi kekuasaan seluruh rakyat."

Kemudian dalam pasal 4 Undang-Undang Pokok Agraria menjelaskan bahwa terdapat macammacam hak yang dapat dimiliki oleh orang perorangan maupun badan hukum. Sebagai pemilik atas hak suatu tanah maka baik orang perorang maupun badan hukum ini diberi hak. Sama halnya dengan konsep dikuasai oleh negara, maka pihak yang mempunyai hak tetap memperhatikan batasbatas kewajaran dalam mengolah dan mengelola tanah tersebut. Apabila nantinya terdapat suatu hal yang berhubungan dengan kepentingan seluruh rakyat Indonesia maka akan kembali kepada negara.

Pengabdian masyaakat ini dilatar belakangi karena kurangnya pengetahuan dan pemahaman masyarakat terkait peningkatan status Hak Guna Bangunan menjadi Hak Milik khususnya di Desa Satria Jaya Kecamatan Tambun Utara Kabupaten Bekasi. Kami memilih tempat pengabdian di desa Satria Jaya karena di Desa ini terdapat Perumahan yaitu Perum Graha Prima yang diperuntukkan bagi PNS dan Anggota TNI yang bersertifikat HGB. Hampir sebagian besar penduduk di perumahan tersebut tidak mengetahui bagaimana persyaratan dan caranya untuk merubah status hak dari Hak Guna Bangunan (HGB) menjadi Hak Milik. Hal ini sangat penting diketahui oleh penduduk Perumahan Graha Prima karena pada saat ini pemerintah sedang gencar melakukan pembangunan fasilitas umum khususnya pembangunan jalan tol. Dikhawatirkan jika sewaktu-waktu Perumahan Graha Prima masuk ke dalam daerah pembangunan untuk jalan tol, maka HGB yang sudah berubah menjadi Hak Milik akan terlindungi. Yaitu sebagai contoh penduduk perumahan Graha Prima akan menerima ganti kerugian yang adil dan layak. Penyuluhan ini juga menjadi penting dikarenakan HGB di Perum Graha Prima akan berakhir pada tahun 2023 maka bagi yang ingin memperpanjang HGBnya maka sudah harus mempersiapkan dokumen-dokumennya. Juga kami menganggap penyuluhan kami sangat penting untuk memberikan pencerahan kepada penduduk perumahan Graha Prima.

Berdasarkan latar belakang diatas dapat dirumusan permasalah dalam pelaksanaan pengabdian masyarakat adalah bagaimana peningkatan status hak tanah yang mulanya hak guna bangunan menjadi hak milik? 


\section{METODE PELAKSANAAN PKM}

Pelaksanaan kegiatan pengabdian kepada masyarakat di wilayah RT. 002/10 Kelurahan Satria Jaya Kecamatan Tambun Utara Kabupaten Bekasi dalam bentuk penyuluhan dimaksudkan untuk memberikan Sosialisasi mengenai Hukum Pertanahan. Adapun tahapan pelaksanaan kegiatan yang dilakukan diawali dengan tahapan persiapan, tahapan pengabdian masyarakat, monitoring dan pendampingan, evaluasi dan pembuatan laporan.

Pengabdian kepada masyarakat dilakukan dengan khalayak sasaran masyarakat Kelurahan Satria Jaya khususnya di Perum Graha Prima Tambun Utara dengan tujuan dapat memberikan pemahaman (sosialisasi) tentang hukum Peningkatan status HGB menjadi Hak Milik dan akibat hukumnya kepada masyarakat dilingkungannya sejumlah 20 orang.

Dalam pelaksanaan pengabdian pada masyarakat dilakukan hal-hal sebagai berikut ; 1 . Kegiatan pelaksanaan penyuluhan dilakukan secara virtual dengan mempergunakan aplikasi Zoom, pelaksanaan pengabdian pada masyarakat dilaksanakan di wilayah RT. 002/10 Kelurahan Satria Jaya Kecamatan Tambun Utara Kabupaten Bekasi, dengan jumlah peserta sebanyak 20 orang, sarana prasarana berupa laptop, dan jaringan internet, dan lainnya semua disiapkan oleh tim pengabdi, dengan susunan acara ; pembukaan (penjelasan tentang maksud dan tujuan dilaksanakanya abdimas), kemudian dilanjutkan materi pengabdian masyarakat oleh tim pengabdi dan materi diberikan dalam bentuk power point kepada setiap peserta sekaligus dilanjutkan dengan acara tanya jawab dan ini dilakukan sebanyak 2 (dua ) sesi.

Pada awal dan akhir kegiatan pengabdian masyarakat dilakukan evaluasi, dimana peserta pengabdian masyarakat mengisi kuesioner yang telah disiapkan oleh tim pengabdi sebanyak 20 orang berdasarkan khalayak sasaran yang telah ditentukan dan seluruh kuesioner dikembalikan kepada tim pengabdi. Adapun tujuan dilakukan evaluasi adalah untuk mengetahui sampai sejauh mana pemahaman materi yang telah disampaikan dan tanggapan dari setiap peserta terhadap pelaksanaan pengabdian masyarakat, hasil kuesioner pemahaman materi sebagaimana tercantum pada tabel 1 dan 2 dibawah ini :

Tabel 1. Kuesioner Sebelum Pelaksanaan Abdimas

\begin{tabular}{|c|c|c|c|c|c|c|c|}
\hline \multirow[t]{2}{*}{ No. } & \multirow[t]{2}{*}{ Pertanyaan } & \multicolumn{6}{|c|}{ Kriteria } \\
\hline & & M & $\%$ & KM & $\%$ & $\mathrm{TM}$ & $\%$ \\
\hline 1 & $\begin{array}{l}\text { Apakah anda mengetahui tentang Undang-Undang } \\
\text { Pokok Agraria? }\end{array}$ & 0 & 0 & 16 & 100 & 4 & $\%$ \\
\hline 2 & $\begin{array}{l}\text { Apakah anda mengetahui perbedaan HGB dan } \\
\text { Hak Milik? }\end{array}$ & 0 & 0 & 0 & 0 & 20 & 100 \\
\hline 3 & $\begin{array}{l}\text { Apakah anda mengetahui tentang syarat dan } \\
\text { prosesur untuk pengajuan peningkatan status } \\
\text { HGB menjadi Hak Milik? }\end{array}$ & 0 & 0 & 0 & 0 & 20 & 100 \\
\hline
\end{tabular}

Pada tabel 1, menunjukkan hasil untuk pengenalan tentang pengenalan tentang Undang-Undang Pokok Agraria Nomor 5 Tahun 1960, Hak Guna Bangunan sebanyak 16 orang menyatakan kurang mengerti dan 4 orang $(\%)$ menyatakan tidak mengerti. Untuk perbedaan hak milik dengan hak guna bangunan sebanyak 20 orang ( \%) menyatakan Tidak mengerti (100\%) menyatakan tidak mengerti. Untuk syarat dan prosedur untuk peningkatan status HGB menjadi Hak Milik sebanyak 20 orang menyatakan $(100 \%)$ menyatakan tidak mengerti. 
Tabel 2. Kuesioner Setelah Pelaksanaan Abdimas

\begin{tabular}{|c|c|c|c|c|c|c|c|}
\hline \multirow[t]{2}{*}{ No. } & \multirow[t]{2}{*}{ Pertanyaan } & \multicolumn{6}{|c|}{ Kriteria } \\
\hline & & $\mathrm{M}$ & $\%$ & KM & $\%$ & TM & $\%$ \\
\hline 1 & $\begin{array}{l}\text { Apakah anda mengetahui tentang Undang- } \\
\text { Undang Pokok Agraria? }\end{array}$ & 15 & 75 & 5 & 25 & 0 & 0 \\
\hline 2 & $\begin{array}{l}\text { Apakah anda mengetahui perbedaan HGB dan } \\
\text { Hak Milik? }\end{array}$ & 15 & 75 & 5 & 25 & 0 & 0 \\
\hline 3 & $\begin{array}{l}\text { Apakah anda mengetahui tentang syarat dan } \\
\text { prosesur untuk pengajuan peningkatan status } \\
\text { HGB menjadi Hak Milik? }\end{array}$ & 20 & 100 & 0 & 0 & 0 & 0 \\
\hline
\end{tabular}

Pada tabel 2, menunjukkan hasil untuk pengenalan tentang UU Agraria sebanyak 15 orang (75\%) menyatakan mengerti, 5 orang $(25 \%)$ menyatakan kurang mengerti. Untuk pemehaman hak guna bangunan sebanyak 15 orang $(75 \%)$ menyatakan mengerti, 5 orang $(25 \%)$ menyatakan kurang mengerti. Tentang syarat dan prosedur untuk pengajuan peningkatan status HGB menjadi hak Milik sebanyak 20 orang (100\%) menyatakan mengerti.

Hasil analisis tanggapan peserta abdimas sebelum dan sesudah pelaksanaan menunjukkan bahwa, untuk pengenalan tentang peningkatan status HGB menjadi Hak Milik adanya peningkatan semula $0 \%$ menjadi $75 \%$ menyatakan mengerti, semula $10 \%$ menjadi $75 \%$ menyatakan kurang mengerti, dan semula $100 \%$ menjadi $25 \%$ menyatakan tidak mengerti.

Beberapa faktor yang mendukung kegiatan pengabdian masyarakat ini dapat berjalan sesuai rencana dikarenakan peserta pengabdian mempunyai keingintahuan yang besar mengenai sosialisasi peningkatan status HGB menjadi Hak Milik, hal ini terbukti dengan jumlah peserta yang hadir melebihi dari yang direncanakan. Faktor pendukung lainnya adalah adanya dukungan baik moril maupun materil dari kalangan Universitas/ Fakultas, Kelurahan dan pihak-pihak terkait lainnya, sedangkan tim pengabdi sampai saat ini tidak mengalami kendala yang cukup berar

\section{HASIL DAN PEMBAHASAN}

Pelaksanaan Pengabdian masyarakat yang diselenggarakan pada tanggal 2 Agustus 2020 yang dilakukan oleh Dosen-Dosen Fakultas Hukum UPN Veteran Jakarta Dr. Atik Winanti, SH, MH, Taupiqqurrahman, SH, M.Kn" Rosalia Dika A, SH, MH berjalan dengan lancar dan mendapat antusias dari masyarakat setempat. Berdasrkan hasil pelaksanaan pengabdian masyarakat adalah sebagai berikut:

\section{A. Hak Guna Bangunan}

Hak Guna Bangunan adalah Hak Milik untuk mendirikan dan mempunyai bangunanbangunan atas tanah yang bukan miliknya sendiri, dengan jangka waktu paling lama 30 tahun dan dapat diperpanjang dengan 20 tahun, dapat beralih dan dialihkan kepada pihak lain. Dapat dijadikan jaminan hutang dibebani Hak Tanggungan. (Utomo, Budi, 2013) Dalam Pasal 30 undang-Undang Nomor 5 Tahun 1960 bahwa yang dapat memiliki hak guna bangunan adalah warganegara Indonesia daan badan hukum yang didirikan menurut hukum Indonesia dan berkedudukan di Indonesia. Hak guna bangunan terjadi :

a. Mengenai tanah yang dikuasai langsung oleh Negara: Karena penetapan pemerintah; dan 
b. Mengenai tanah milik : karena perjanjian yang berbentuk otentik antara pemilik tanah yang bersangkutan dengan pihak yang akan memperoleh hak guna bangunan itu, yang bermaksud menimbulkan hak tersebut.

Bila di atas menjelaskan tentang definisi dan sebab terjadi hak guna bangunan. Dimana hak guna bangunan merupakan hak yang dinerikan dengan jangka waktu tertentu. Tentu apabila jangka waktu tersebut berakhir, maka hak guna bangunan tersebut bias hapus. Secara umum, yang menjadi penyebab hapusnya Hak guna bangunan hapus karena :

a. jangka waktunya berakhir;

b. dihentikan sebelum jangka waktunya berakhir karena sesuatu syarat tidak dipenuhi;

c. dilepaskan oleh pemegang haknya sebelum jangka waktunya berakhir;

d. dicabut untuk kepentingan umum;

e. ditelantarkan;

f. tanahnya musnah;

Penyuluhan yang dilaksanakan salah satunya adalah penekanan kepada masyarakat setempat untuk melihat kapan harus melaksanakan perpanjangan HGB. Mengingat apabila HGB tersebut sudah berakhir, maka HGB tersebut tidak bisa diperpanjangkan lagi. Karena syarat perpanjang HGB salah satunya adalah sebelum jangka waktunya habis. Lebih jelasnya persyaratan perpanjangan HGB adalah sebagai berikut:

1. Isi formulir permohonan di loket pelayanan kantor Badan Pertanahan Nasional (BPN)

2. Surat Kuasa apabila dikuasai

3. Fotokopi KTP dan KK pemohon

4. Fotokopi Akta Pendirian dan Pengesahan Badan Hukum yang telah dicocokkan dengan aslinya oleh petugas loket

\section{Sertifikat asli}

6. Fotokopi SPPT PBB tahun berjalan yang telah dicocokkan dengan aslinya oleh petugas loket dan bukti Pembayaran Uang Pemasukan

Adapun langkah yang dilakukan adalah pemohon dengan datang langsung ke Badan Pertanahan Setempat, yaitu dimana lokasi tanah atau HGB tersebut berada. Di sana Anda langsung datang ke loket pelayanan dan mengisi formulir pengajuan, saat mengisi jangan lupa untuk mengisi identitas diri, luas, letak dan penggunaan tanah yang dimohon, peryataan tanah tidak sengketa dan pernyataan tanah dikuasai secara fisik.

\section{B. Hak Milik}

Hak milik merupakan hak yang dimiliki oleh seseorang secara turu temurun, terkuat dan terpenuh. Turun-temurun artinya hak milik atas tanah dapat berlangsung terus selama pemiliknya masih hidup dan pemiliknya meninggal dunia, maka hak miliknya dapat dilanjutkan oleh ahli warisnya sepanjang memenuhi syarat sebagai subjek hak milik. Terkuat, artinya hak milik atas tanah lebih kuat bila dibandingkan dengan hak atas tanah yang lain, karena tdk mempunyai batas waktu tertentu, mudah dipertahankan dari gangguan pihak lain, dan tidak mudah hapus. Terpenuh, artinya 
hak milik atas tanah memberi wewenang kepada pemiliknya paling luas bila dibandingkan dengan hak atas tanah yang lain, karena HM tidak berinduk pada hak atas tanah yang lain.

Bila dilihat dari uraian tersebut terlihat, bahwa hak milik ini bagian dari hak-hak atas tanah, adapun ha katas tanah sebagaimana diatur dalam Pasal 16 UUPA antara lain sebagai berikut:

1) hak milik,

2) hak guna usaha,

3) hak guna bangunan,

4) hak pakai,

5) hak sewa,

6) hak membuka tanah,

7) hak memungut hasil hutan,

Hak milik diperoleh melalui 3 (tiga) hak tersebut tertuang dalam Pasal 22 UUPA uaitu, pertama hak milik atas tanah yang terjadi menurut hukum adat, kedua hak milik atas tanah terjadi karena penetapan pemerintah dan ketiga hak milik atas tanah terjadi kerena ketentuan undang-undang. Hak milik atas tanah yang terjadi menurut hukum adat yatiu ak milik atas tanah terjadi dengan jalan pembukaan tanah (pembukaan hutan) atau terjadi karena timbulnya lidah tanah (Aanslibing). Hak milik atas tanah terjadi karena penetapan pemerintah, bahwa hak milik atas tanah yang terjadi disini berasal dari tanah Negara. Hak milik atas tanah ini terjadi kerena permohonan pemberian hak milik atas tanah oleh pemohon dengan memenuhi prosedur dan persyaratan yang telah ditentukan oleh BPN. Kemudian hak milik atas tanah terjadi kerena ketentuan undang-undang dimana hak milik atas tanah ini terjadi karena undang-undang lah yang menciptakannya yaitu ketentuan-ketentuan Konversi dalam UUPA.

\section{Peningkatan Status Hak Guna Menjadi Hak Milik}

Uraian tentang HGB dan Hak Milik, menjadi landasan kuat kenapa seseorang harus meningkatkan status hak tanah tersebu. Sebagaimana diketahui bahwa Hak Milik merupakan hak yang terkuat dan terpenuh sedangkan HGB dibatasi oleh wajtu tertentu. Artinya apabila tidak ditingkatkan statusnya, maka hak tersebut bisa hapus seiring dengan waktu. Hak Milik bisa menjadi induk dari HGB, dengan kata lain, bahwa HGB bisa saja ada di atas hak milik. Dalam istilah hukum agrarian, yaitu asas pemisahan horizonatal, dimana asas yang memisahkan kepemilikan hak atas tanah dengan hak guna bangunan. Mengingat perumahan tempat dilakukan pengabdian, status hak atas tanahnya adalah HGB, maka salah satu solusi yang kami berikan agar masyarakat setempat meningkatkan status hak guna bangunan menjadi hak milik.

Dalam permohonan peningkatan status ha katas atas tersebut, ada beberapa persyaratan yang harus dipenuhi, antara lain adalah:

1. Fotokopi KTP Pemohon.

2. Fotokopi Kartu Keluarga

3. Surat Kuasa jika dikuasakan.

4. Fotokopi SPPT PBB tahun terakhir. 


\section{Sertifikat HGB.}

\section{Fotokopi IMB.}

Selain dari syarat di atas, maka yang tidak kalah pentingnya adalah bahwa HGB tersebut tidak diikat dengan Hak Tanggungan. Hak Tanggungan diatur di dalam UU Nomor 4 Tahun 1996 mengatur lembaga jaminan yang disebut Hak Tanggungan. Lembaga jaminan hak tanggungan digunakan untuk mengikat objek jaminan utang yang berupa tanah atau benda-benda yang berkaitan dengan tanah yang bersangkutan.adapun definisi dari hak tanggungan adalah hak jaminan yang dibebankan pada hak atas tanah sebagaimana dimaksud dalam UUPA, berikut atau tidak berikut benda-benda lain yang merupakan suatu kesatuan dengan tanah itu, untuk pelunasan utang tertentu, yang memberikan kedudukan yang diutamakan kepada kreditor terhadap kreditorkreditor lain. Apabila HGB tersebut diikat dengan Hak Tanggungan, maka ada persyaratan tambahan yaitu harus adanya surat persetujuan dari kreditor selaku pemegang hak tanggungan.

Mengenai biaya pendaftaran perubahan hak guna bangunan menjadi hak milik, diatur dalam Peraturan Pemerintah Nomor 128 Tahun 2015 tentang Jenis dan Tarif Atas Jenis Penerimaan Negara Bukan Pajak Yang Berlaku Pada Kementerian Agraria Dan Tata Ruang/Badan Pertanahan Nasional yaitu sebsar Rp. 50.0000 (Lima Puluh Ribu Rupiah) perbidang.

\section{KESIMPULAN DAN SARAN}

\section{A. Kesimpulan}

1. Adapun bahwa hak milik merupakan hak yang dimiliki oleh seseorang secara turun temurun, terkuat dan terpenuh. Sehingga hak milik tidak berinduk pada hak atas tanah yang lain melainkan hak atas tanah lainnya yang berinduk kepada hak milik

2. Masyarakat tempat dilakukan pengabdian, rata-rata hak katas tanahnya adalah hak guna bangunan

3. Sebelum dilaksanakan penyuluhan, masih sedikitnya masyarakat yang paham perbedaan antara hak milik dengan hak guna bangunan

4. Setelah dilaksanakan penyuluhan, masyarkat mengetahui perbedaan hak-hak atas tanah dan bagaimana proses peningkatan status hak guna bangunan menjadi hak milik

\section{B. Saran}

Adapun saran yang diberikan yaitum apabila HGB segera melakukan proses permohonan peningkatan status ha katas tanah kepada Badan Pertanahan Nasional setempat.

\section{Ucapan Terima Kasih (Acknowledgement)}

Dalam penulisan laporan ini, tim mengucapkan terimakasih kepada masyarakat Perum Graha Prima Desa Satria Jaya Kecamatan Tambun Utara Kabupaten Bekasi. Kepada Pimpinan Fakultas Hukum dan Kepada pihak LPPM.

\section{REFERENSI}

Kartasapoetra. G. dkk. 1991. Hukum Tanah Jaminan Undang-undang Pokok Agraria bagi Keberhasilan Pendayagunaan Tanah. PT. Rineka Ciptam,, Jakarta.

Utomo, Budi, 2013, Hukum Perdata, Penerbit Sejahtera, Yogyakarta. 
G.Kartasapoetra Hukum Tanah Jaminan Undang-undang Pokok Agraria bagi Keberhasilan Pendayagunaan Tanah, Rineka Cipta, Jakarta.

Undang-Undang Nomor 5 Tahun 1960 tentang Peraturan Pokok-Pokok Agraria

Undang-Undang Nomor 4 Tahun 1996 tentang Hak Tanggungan 